\title{
Education, Work and Number of Children
}

\author{
OLAVI RIIHINEN \\ Professor \\ Department of Social Policy \\ University of Helsinki
}

AIMO PULKKINEN

Director

MARKETTA RITAMIES

HELI PENTTINEN

Research Associates

The Population Research Institute

\section{The effect of industrialization on the family}

As the number of children in western societies drops to ever lower levels, researchers are ever more at a loss when pondering the reasons for this development. The decline in the birth rate has continued with certain exceptions for almost the entire period of industrialization (Strömmer 1969, 49-54). Consequently, this development has generally been connected with industrialization. Some researchers have emphasized the significance of structural changes which have occurred in society during industrialization, while others have pointed to the effect of new values.

The decline in the birth rate has also been seen as part of a general change in the structure and functions of the family. A small number of children has very often been linked with the nuclear family, and this has, primarily in accordance with Parson's view, been regarded as a result of industrialization. Although Parsons did not attempt to elaborate a theory on the development of the birth rate, his ideas on the changes undergone by the structure and functions of the family have undoubtedly also affected decisions made with respect to the birth rate.

According to Parsons's view the new industrial system functions in a manner which emphasizes achievement, functional specificity, universalism, and affective neutrality. But these values are contrary to the traditional values concerning the family, where the emphasis is more frequently on ascription, functional diffuseness, particularism, and affectivity (Parsons and Bales 1955). 
According to Parsons and several other researchers (cf. e.g. Kerr et al. 1960) a deep conflict exists between the traditional family institution and the modern industrial system. However, since in the industrial system the family performs the necessary function of reproducing the labor force, the conflict has had to be resolved. Parsons and many others have assumed that the answer lies in the nuclear family.

According to these researchers the extended family, which consists of three generations and several nuclear family -like units within the same household, is not suited to the industrial system. One of the arguments they present in support of this view is that when it is dominant, family duties and ties are stronger than the duties related to one's work. Thus the extended family suppresses individual incentives to work, save, and invest. The extended family also curtails regional and social mobility (Kerr et. al. 1960, 78-82).

According to Parsons, the family is necessary in the industrial system, not only as a producer of labor, but also as a counterbalance to instrumental activity, i.e. to work. The family is needed as a means for expressive activity (Parsons and Bales 1955, 309-312). The release of emotional tension has indeed been seen as an essential function of the family. It has been claimed that the husband's role as a father and the wife's role as a mother have strengthened along with industrialization and the development of the nuclear family.

But Parsons feels that an important part of this development has also been the instrumentalization of the husband's role and the expressionalization of the wife's role: The husband has been forced more clearly than before to carry the responsibility for the family's material subsistence and its relations with the outside world, while the wife has more clearly concentrated on the family's internal affairs, and she has become the soul of the home (Parsons and Bales 1955, 3-33).

Parsons's conclusion with respect to the effect of industrialization on the birth of the nuclear family has, as is well-known, been shown to be faulty. In the pioneering industrial country of England, at least, the institution of the nuclear family was already common before industrialization (Laslett 1972).

But equal criticism should be focused on Parsons's claim concerning the husband's increasing instrumental leadership and the wife's growing emotional and expressive role as industrialization progresses. In fact, there seems to be a logical contradiction between the changes in values Parsons presents, and the change in the family institution which he describes. If increasingly more emphasis is placed in society on achievements instead of on ascription, on universalism instead of on particularism and on affective neutrality instead of on affectivity, why should this change not also be reflected in the attitudes and values of women?

The assertation concerning the husband's increasing instrumental leadership and the wife's growing emotional role can be demonstrated to be dubious already on the basis of normal everyday observations. Statistics on the education and employment of women, however, demonstrate drastically that Parsons's conclusions were drawn on the basis of a sample which was entirely too narrow in time and in area. 


\section{The education and employment of Finnish women}

Finland is an example of a country where the education and employment of women differ sharply from that which is assumed on Parsons's descriptions of the nuclear family. Today the education of women reaches the same level as that of men, and it has become increasingly common for women to hold a job.

Already in 1930 a slightly larger percentage of women than men had completed elementary school. Since the rate of illiteracy in Finland seems to be one of the lowest in the world, information concerning the lowest educational level of half a century ago is significant only because it foretold later development with respect to education on a higher level. Nowadays the proportion of girls among upper secondary school students is notably higher than that of boys, the same is true of students passing the matriculation examination. In 1901, when the university was officially opened to women, they constituted 13.8 percent of the students. More than half a century later, in the academic year of 1964-65, the student structure in Finnish universities became one in which women constituted the majority. Although the female majority is slight, it has shown to be gradually increasing, and in many university departmens people are already pondering what the future consequences of this increasing female majority will be (cf. Haavio-Mannila 1968, 43-44; Elinolosuhteet 1950-1975, 1977, 94).

The increase of high-level education among women has made it at least partially possible for women to participate in the labor force to an ever greater degree. This development is not restricted to single women alone. When we examine Finnish families which included both parents and at least one child under 18, we find that in 196045 percent of these mothers were employed. But by 1975 this percentage had risen to 67 . This trend appears even steeper if we leave out the "mother family workers», mainly farmer's wives, who have been included in the above-mentioned figures, and examine only wage earners and entrepeneurs: in 196024 percent of mothers in families with children were wage earners or entrepeneurs, in 1975 the figure was already 60 percent (cf. Suominen 1979, 51).

\section{The relationship of number of children to education and employment}

Although the nuclear family does not seem to have been a new social creation brought about by industrialization, marked changes in family structure have nonetheless occurred during the industrialization period. The increase in the education of married women and the rapid increase in their employment outside the home also form a part of these changes, at least during recent decades.

The fertility surveys made in various countries and in different cultures give a quite many sided picture of the correlations between education and the number of children. Nevertheless, a negative correlation between these variables is clearly encountered with the greatest frequency. Research results for developing countries, 
based on aggregate data, show that a negative correlation is more common when examining urban areas than when examining rural ones. It is also more common in countries somewhat advanced in their level of development than in the poorest countries. Studies concerning developing countries and based on information on individuals indicate that fertility at the lowest level of aggregate literacy is often higher among persons with some amount of education than among persons with no education at all.

Studies concerning the developing countries and based on information on individuals also show that the education of women is more likely to be inversely related to fertility than the education of men is. When the effect of income is eliminated, this inverse relationship is strengthened among women, but not among men (Cochrane 1979, 50-51).

In developed countries a negative correlation between education and the number of children also appears to be most common. Thus, the National Fertility Study made in the United States at the end of the 1960s found this result (Ryder and Westoff, 54; cf. Andorka 1978, 260-261). In Europe, on the other hand, it has been quite common for a $\mathrm{U}$-shaped relation to appear between education and fertility, although there have also been studies demonstrating the usual inverse relationship (Andorka 1978, 261-265).

The inverse relationship between the employment of married women outside the home and the number of children is probably even more common than the similar relation between the education of women and fertility. But not even this relationship seems to be universal. In some developing countries there is probably no noticeable correlation between the said variables (Kupinsky 1977, 376-377). In developing countries, on the other hand, it has been shown that at least the number of children of married women employed full time is, on the average clearly smaller than that of married women who are at home. The causal relationships between the employment of married women and number of children are difficult to interpret, since the effects may be reciprocal (Andorka 1978, 295-297).

\section{The purpose of this article and the material used}

The correlations between the number of children in a family and the education and employment of the parents have been studied very little in Finland. This article attempts to examine these correlations using a limited number of variables. The material from which these variables originate, the Finnish Fertility Survey, would make it possible to use a markedly broader group of variables in order to examine the correlations in question. However, since these questions are dealt with more thorougly in the research reports themselves, we will limit ourselves here to an examination of only a few variables.

The Finnish Fertility Survey is part of the World Fertility Survey, although the approach used in the Finnish survey is more theoretical and, therefore, the composition of variables used in it differs considerably from that used in the World Fertility 
Survey. The original sample in the Finnish survey totalled 6200 and it was composed of 18-44-year-old women in their first marriage. The sample covers Finland as a whole, excluding the Åland Islands, and the interviews were made in spring 1977 . Because of divorce, separation, and other similar reasons, the original sample dropped to 6001 persons. For various reasons a total of 566 women were not interviewed, thus forming a loss percentage of 9.4 (Riihinen et al. 1980, 21-23). Because the population register, from which the sampling was made was for the end of 1976, and the interviews were made in spring 1977, the sample also included some 45-years-old women. For the same reason all of the sample's 18-year-old married women had already turned 19 by the time the interviews were made.

The proportion of married women in the labor force in Finland is perhaps higher than in any other Western European country. In 1977 the percentages of married women in the labor force were, according to the Official Statistics of Finland (XL.2.) and the data in this study, the following:

$\begin{array}{ccc}\text { Age class } & \text { Entire country } & \text { This study } \\ 15-19 & 48.4 & \ldots \\ 20-24 & 65.0 & 62.6(19-24) \\ 25-29 & 73.0 & 73.9 \\ 30-34 & 77.6 & 75.8 \\ 35-39 & 81.3 & 82.7 \\ 40-44 & 84.0 & 84.4(40-45)\end{array}$

In the entire data of the Finnish Fertility Survey the proportion employed was 77.3 percent.

Because the amount of education among women has risen quite rapidly in the last few decades, there has perhaps been a tendency to assume that the increase in the employment of married women might also be caused by education. This study, however, does not support this assumption to any great extent, as can be seen in the following table. It shows the educational distribution of the entire sample and the proportion employed among the 35-45-year-olds according to educational class:

Educational class

Elementary school

Elementary school and vocational school

Lower secondary school

Lower secondary school

and vocational school
Percentage of The percentage of all classes employed 35-45-

year-olds in the educational class
44.3

18.3

10.8

3.6
81.0

87.8

87.0 
Lower secondary school and

vocational-technical collage

Matriculation examination or matriculation examination and vocational school

Matriculation examination and vocational-technical collage

Academic degree

Total

100.0

\section{Correlations between education and the number of children}

An examination of various countries which differ from each other considerably shows that an inverse relationship most commonly prevails between education and the number of children. But there are also countries and areas where the more educated the parents are the greater the number of children; and a U-shaped relation is found relatively often.

Appendix table 1 shows that in examining the number of live children in itself (col. 1) in Finland, also, the correlation between education and the number of children tends to be weakly U-shaped. However, because education and the number of children are related to age and length of marriage, the picture given by the variable mentioned is not necessarily reliable. A more reliable picture of the relationship is obtained, if a way can be found to eliminate the effects of age and length of marriage. In this study elimination was attempted by calculating the number of children in each family as a deviation value from the average in the age class of the wife, and, correspondingly, from the average per years of marriage and by using these deviation values instead of the original observations. Thus we have found the »excess» $(+)$ or »deficit» $(-)$ in the number of children in appendix table 1 , columns 2 and 3 .

The excess or deficit in the number of children calculated according to the wife's age (col. 2) gives a somewhat different picture of the number of children without this standardization for age. The relationship between education and number of children, however, shows up more clearly than in the unstandardized variable: the highest educational classes consistently get the lowest values. But, on the other hand, standardization according to length of marriage (col. 3) eliminates the majority of the differences between the educational classes. When standardized for age, the difference between persons with an elementary school education and persons with an academic degree is 0.5 children; when standardized for length of marriage the difference was only 0.2 children.

Although small, the major portion of the differences between educational classes are statistically significant. Appendix table 2 shows the differences between the class with an elementary school education and the class with an academic degree and the other educational classes, tested with a t-test. On the basis of the number of live 
children, the lowest educational class, those with an elementary school education, differs very significantly from all the other educational classes (col. $1 \mathrm{~A}$ ). The most highly educated class, however, does not differ from the other classes as clearly (col. $1 \mathrm{~B})$. A similar regularity is repeated when the results reached when standardizing for age are examined (col. $2 \mathrm{~A}$ and $2 \mathrm{~B}$ ), although the differences have decreased slightly in significance. The significance of the differences declines noticeably, when we look at results based on standardization according to length of marriage (col. 3 $\mathrm{A}$ and $3 \mathrm{~B}$ ). The values of the class with an academic degree differ significantly only from the values of the lowest educational class.

A real difference in the number of children seems to appear between the class with an elementary school education and the other educational classes. This difference between the lowest educational class and the other educational classes is reflected also in the expected number of children (Appendix table 1, col. 5; Appendix table 2, col. $5 \mathrm{~A}$ and $5 \mathrm{~B}$ ).

By examining the oldest age classes, the 35-45-year-olds, we have tried to find out what level the final number of children will reach (Appendix table 1, col. 7-10; Appendix table 2, col. $7 \mathrm{~A}-7 \mathrm{~B}$ and $9 \mathrm{~A}-9 \mathrm{~B}$ ). In families where the wife is over 35 , so few children are born anymore, that the number of children in these age classes can, in practice, be considered final. As a whole, the results are similar to those given by other types of age standardizations, although the differences between educational classes seem to decrease with age. There is also reason to take note that classification according to the husband's education changes the results somewhat. Particularly in the two highest educational classes, the number of children comes closer to the average in the entire sample than when examined according to the wife's education.

On the basis of what we have examined so far, we can note that education and factors related to it have the strongest effect on lowering the number of children when we go from the lowest educational class, those with an elementary school education, to other educational classes. Even a slight increase in education after the lowest basic educational level clearly drops the number of children, but after that point, additional education does not seem to have any marked effect on the number of children. This conclusion can be made when examining the entire sample and all the age classes $19-45$ years old and by trying to eliminate the effect of age from the results. This conclusion is also supported by the examination of the expected final number of children. Not even an examination of the oldest age classes in the study, the 35-45-year-olds, changes this conclusion noticeably, even though examining it according to the wife's education does point to some sort of continuous decline in the number of children along with education. The frequencies in the educational classes are so small in these analyses that the differences remain low in significance. This also holds true in the examination according to the husband's education.

The results reflect relatively clearly that, to a great extent, the effects of education are timing effects: people postpone having children. But it must also be noted that the differences especially between the lowest educational class and the other 
educational classes continue to be relatively plain up till the end of the fertile period. In addition, the education of women apparently has a stronger effect on the number of children than does the education of men.

\section{The relations between the wife's education and work and the number of children}

As far as it is possible to compare the speed at which two different matters are developing, it seems that the increase in the employment of married women during the past few decades in Finland has been even faster than the rise in the level of education among women. It has often been assumed that the decrease in the birth rate is connected to the increase in the employment of married women.

It was noted earlier that there does not seem to be any strong correlation, at least, between the educational level attained by married women and their employment frequency. But what are the relations of education and employment with the number of children, if they are examined at the same time in a manner where the effects of each are purified of the effects of the other? Appendix table 3 shows a muiti-variate analysis of this sort, which, in addition, includes the age variable in a three-class form.

It is easy to observe that the number of children of employed married women in the educational and age classes examined is, almost without exception, lower than among married women who are at home. Even the rare exceptions may be explained by the low frequencies in the said classes. It must be remembered, of course, that one should beware of considering the quality of the wife's work as a causal factor: the wife may be staying at home expressly because the number of children in the family has grown.

It is difficult to grasp the information in a multi-variate table without a statistical analysis. Appendix table 4 presents the correlations of three number-of-children variables with the wife's education and work using a two-way analysis of variance. Let us emphasize that although an analysis of variance is mainly meant for explaining causal relationships, here it cannot be used for making clear-cut conclusions concerning causality. We should speak of correlations rather than effects. Therefore, also, not very much attention should be paid to the level of explanation of the models.

An examination of education and work at the same time clearly shows that the number of children is more strongly connected with whether a wife is employed or not than with her education. This observation is true for all the number-of-children variables and all the age classes.

This statistical correlation should not be used, however, to make the conclusion that work would necessarily be a more significant factor in the number of children than education, for the causal relationship of these variables with the number of children is different. Therefore, it is probably impossible to determine which is more significant in decreasing the number of children.

The effects of education on the number of children appear most concretely in the spacing of births. But education also seems to have permanent effects, so that 
the number of children of persons who have risen past the lowest level of education remains permanently at a level lower than those whose education stopped at the lowest level. It is difficult to determine which factors in educaton lead to an increased attempt at limiting the number of children. The effects of education can be searched for in three areas: in changes in information, values and behavior.

The modern school system teaches, above all, so-called means-rational thinking, which is based to a great extent on the causalities of natural science. But at the same time, this way of thinking brings with it new values which emphasize functional efficiency and a striving for efficiency. The value changes of Parsons described above are related mainly to just these changes which modern education is spreading very efficiently. Although it is felt that this type of education which is based on a natural science - positivistic ideal of knowledge emphasizing cause-and-effect relationships usually disseminates facts and information, such an education also has an essential value content related to the new rationality. Thus, education in modern society also clears away the vestiges of the age-old mystical and fatalistic concepts typical of all cultures, concepts which throughout the ages have surrounded the birth event. It is also increasingly rare for religious values and norms to be in conflict with birth control.

This change in the way of thinking seems in part to explain the general decline in fertility. The removal of taboos has led to the efficient use of contraceptives and, at the same time, the methods of contraception themselves have developed.

But education also brings with it changes in outward behavior. There is reason to assume that education increases far-sightedness and planning as much as information. This is, of course, a result of the change in values: the emphasis has gone toward functional rationality.

Schools most likely teach their pupils and students, during the teaching process which lasts for years, above all a systematic, long-term and far-reaching aim to reach certain goals. In fertility behavior these behavior patterns are decisive. They probably also explain why highly educated persons are more successful in the use of contraceptives than persons with a low level of education, although knowledge about contraceptives is about at the same level in different educational classes. These regularities show up quite clearly in the as yet unpublished results of the Finnish Fertility Survey.

The fact that the education of women has qualitatively the same contents as that of men and, on the average, it is at least on the same level, helps to weaken Parsons's assumption concerning the differentiation of male and female roles, the former into an instrumental and the latter into an expressive direction. The increase in the employment of married women together with the rise in the educational level of women no doubt develops the wife's role in an instrumental direction. The traditional division of roles in the family has changed at least in that, increasingly, the wife now has two roles: the one relating to taking care of the home and the other related to her occupation, work and providing for her family.

But at the same time the life plan of women is changing. Previously a woman's life plan was built very much around her home and her family. When the 
significance of education, work and occupation are emphasized in the life plans of women, it is understandable that having children no longer has the same place in this plan.

Without long-term follow-up studies it is difficult to say to what extent women, already at an early date and at the latest before they marry, make choices between various life plans. However, it can be considered probable that plans directed toward occupations are at an increasingly early phase of life and that these plans help lead to low numbers of children.

It is also only with long-term follow-up studies that we can reliably conclude to what extent pregnancies which deviate from these plans change plans directed toward occupations into more family-centered plans. When the relations between the wives' employment and the number of children they have are considered, we should remember in any case, that some of the housewives have stayed at home expressly because of an unplanned pregnancy and increase in the family.

It is easy to understand that many wives who are employed consider having children with reservation. Every small child seems to increase the mother's work load markedly. A survey made in 1977 showed that when a Finnish family had no 0-6-year-old children, the time the wife spent on housework was less than five hours a day. But when there were two children of this age in the family, the time spent on housework rose to 8.6 hours a day; and if there were at least three children of this age, the wife already did almost ten hours of housework (Säntti and Väliaho 1982, 103).

The figures presented above are based on data where some of the wives only took care of the home, some were also employed. The conclusion can be made that a housewife has flexibility in regard to how she uses her time: her work input is probably reasonably sufficient for the care of two or even three small children, without demanding a visible work input from the father or other members of the family. But the total work time of an employed mother reaches the critical point when the number of children grows.

The time employed wives in childless families spent on housework daily was four hours on the average; the husband in corresponding families spent an average of 1.8 hours on housework per day. But if both spouses are employed and there are two 0 -6-year-old children in the family, the amount of housework the wife did rose to 6.7 hours, while the husband's rose only to 2.8 hours (Säntti and Väliaho 1982, 76).

Despite the high total of wage work and housework done by the wife, the internal division of work in the family tends to remain the same. It does seem that employed wives are able to organize the time they spend on housework more efficiently than other wives - or maybe they have to do so. Nevertheless, it is most likely that the double role of outside employment and housework is often a heavy burden.

If we think of educated women as rationally behaving persons concerned about their wellbeing, in the light of these facts, we can hardly reach any other conclusion than that, when they are employed outside the home, they aim at closely planning and limiting the number of children they have. 


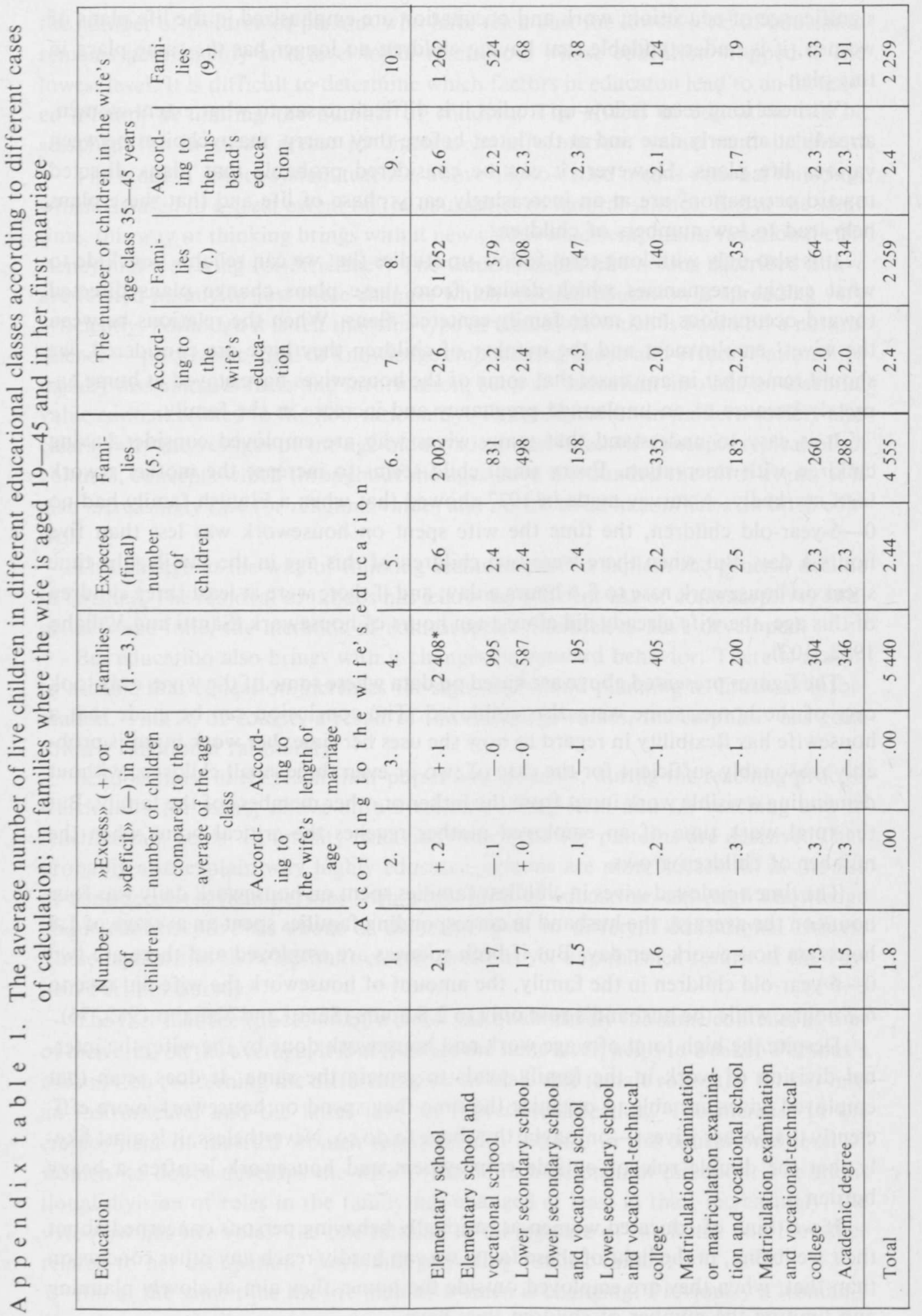




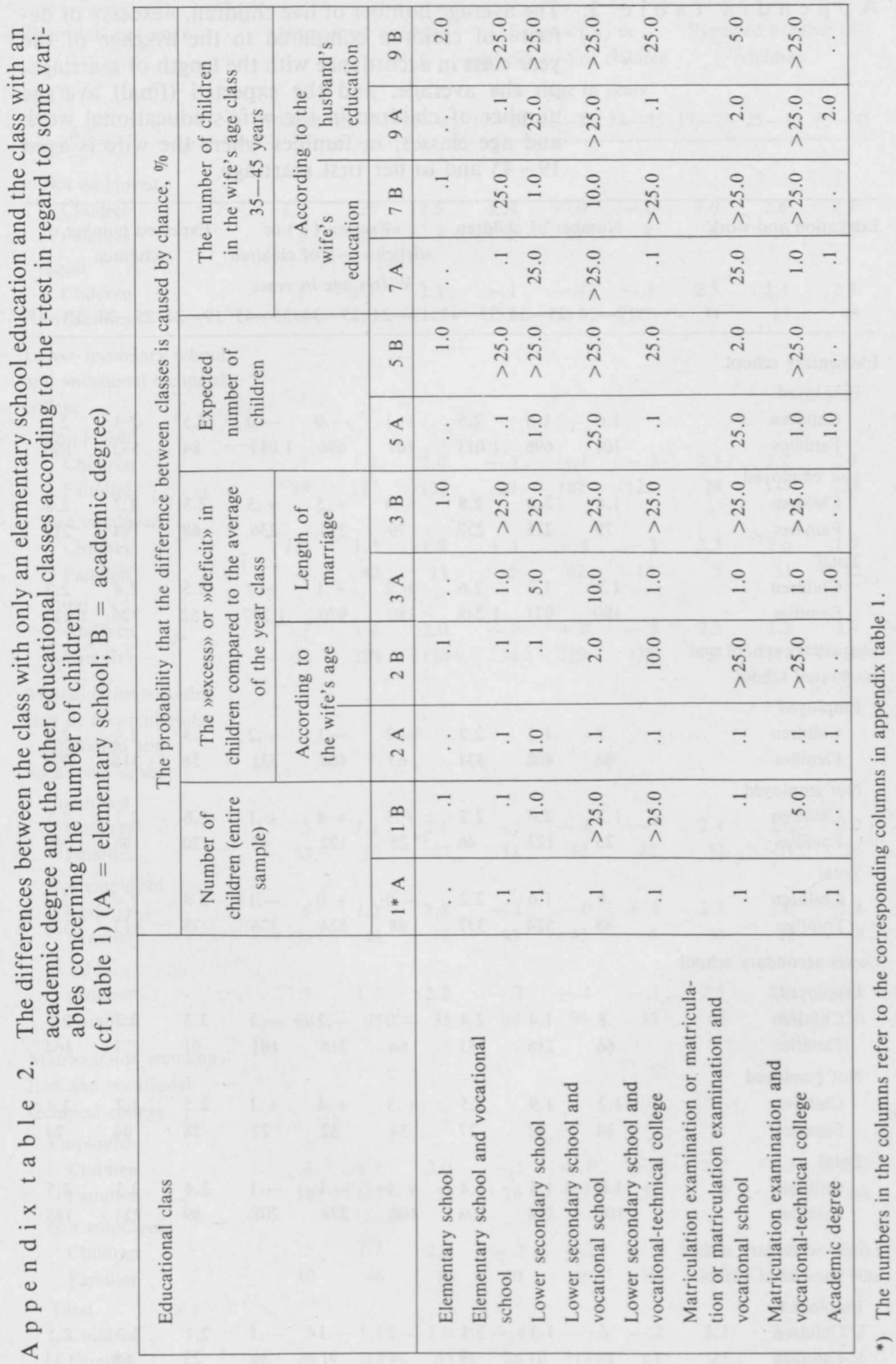


A p p e n d ix t a b l e 3. The average number of live children, »excess» or deficit» of children compared to the average of the year class in accordance with the length of marriage, on the average, and the expected (final) average number of children in the wife's educational work and age classes; in families where the wife is aged $19-45$ and in her first marriage

\begin{tabular}{|c|c|c|c|c|c|c|c|c|c|}
\hline \multirow[t]{2}{*}{ Education and work } & \multicolumn{3}{|c|}{ Number of children } & \multicolumn{3}{|c|}{$\begin{array}{c}\text { »Excess» }(+) \text { or } \\
\text { »deficit» }(-) \text { of children } \\
\text { Wife's age in years }\end{array}$} & \multicolumn{3}{|c|}{$\begin{array}{c}\text { Expected number of } \\
\text { children }\end{array}$} \\
\hline & $19-24$ & $25-34$ & $35-45$ & $19-24$ & $25-34$ & $35-45$ & $19-24$ & $25-34$ & 435 \\
\hline \multicolumn{10}{|l|}{ Elementary school } \\
\hline \multicolumn{10}{|l|}{ Employed } \\
\hline Children & 1.0 & 1.6 & 2.5 & +.1 & -.0 & -.0 & 2.5 & 2.3 & 2 \\
\hline Families & 101 & 696 & 1011 & 101 & 696 & 1011 & 84 & 532 & 8 \\
\hline \multicolumn{10}{|l|}{ Not employed } \\
\hline Children & 1.4 & 2.0 & 2.8 & +.4 & +.5 & +.3 & 2.5 & 2.7 & 2 \\
\hline Families & 79 & 275 & 237 & 79 & 274 & 230 & 68 & 194 & 21 \\
\hline \multicolumn{10}{|l|}{ Total } \\
\hline Children & 1.2 & 1.7 & 2.6 & +.2 & +.1 & +.0 & 2.5 & 2.4 & 2 \\
\hline Families & 180 & 971 & 1248 & 180 & 970 & 1247 & 152 & 726 & 111 \\
\hline
\end{tabular}

Elementary school and

vocational school

Employed

Children

Families

$\begin{array}{rrrrrrrrr}.7 & 1.5 & 2.2 & -.2 & -.1 & -.2 & 2.3 & 2.4 & 2.3 \\ 63 & 402 & 331 & 63 & 402 & 331 & 58 & 315 & 294\end{array}$

Not employed

Children

Families

$\begin{array}{lllllllll}63 & 402 & 331 & 63 & 402 & 331 & 58 & 315 & 294\end{array}$

Total

Children

Families

$\begin{array}{lllllllll}1.2 & 2.0 & 2.3 & +.3 & +.4 & +.1 & 2.6 & 2.7 & 2.5\end{array}$

$\begin{array}{lllllllll}.8 & 1.6 & 2.2 & -.0 & +.0 & -.1 & 2.4 & 2.4 & 2.3\end{array}$

$\begin{array}{lllllllll}88 & 524 & 337 & 88 & 524 & 376 & 78 & 413 & 334\end{array}$

Lower secondary school

Employed

Children

Families

$\begin{array}{rrrrrrrrr}.8 & 1.4 & 2.4 & -.0 & -.2 & -.1 & 2.3 & 2.2 & 2.5 \\ 66 & 216 & 181 & 66 & 216 & 181 & 61 & 177 & 164\end{array}$

Not employed

Children

Families

$\begin{array}{rrrrrrrrr}1.2 & 1.9 & 2.5 & +.3 & +.4 & +.1 & 2.5 & 2.7 & 2.4 \\ 34 & 62 & 27 & 34 & 62 & 27 & 28 & 44 & 24\end{array}$

Total

Children

Families

$\begin{array}{lllllllll}1.0 & 1.5 & 2.4 & +.1 & -.1 & -.1 & 2.4 & 2.3 & 2.5\end{array}$

Lower secondary school and vocational school

Employed

Children

Families

$\begin{array}{rrrrrrrrr}.6 & 1.3 & 2.3 & -.2 & -.1 & -.1 & 2.1 & 2.3 & 2.5 \\ 24 & 91 & 39 & 24 & 91 & 39 & 22 & 68 & 33\end{array}$


Education and work

Number of children „Excess" $(+)$ or »deficit» (-) of children
Expected number of children

Wife's age in years

$19-24 \quad 25-34 \quad 35-45 \quad 19-24 \quad 25-34 \quad 35-45 \quad 19-24 \quad 25-34 \quad 35-45$

$\begin{array}{lrrrrrrrrr}\text { Not employed } & & & & & & & & \\ \text { Children } & 1.2 & 1.5 & 2.5 & +.4 & -.0 & -.0 & 3.0 & 2.6 & 2.7 \\ \text { Families } & 9 & 24 & 8 & 9 & 24 & 8 & 9 & 19 & 7 \\ \text { Total } & & & & & & & & & \\ \text { Children } & .8 & 1.3 & 2.3 & -.1 & -.1 & -.1 & 2.3 & 2.4 & 2.5 \\ \text { Families } & 33 & 115 & 47 & 33 & 115 & 47 & 31 & 87 & 40\end{array}$

Lower secondary school and vocational-technical college

\section{Employed \\ Children \\ Families
Not employed
Children \\ Families}

Total

Children

Families

$\begin{array}{rrrrrrrrr}.7 & 1.4 & 2.0 & -.1 & -.1 & -.3 & 2.3 & 2.2 & 2.1 \\ 29 & 187 & 125 & 29 & 187 & 125 & 28 & 147 & 108 \\ & & & & & & & & \\ 1.0 & 1.8 & 1.8 & +.1 & +.4 & -.3 & 2.3 & 2.6 & 1.9 \\ 5 & 42 & 13 & 5 & 42 & 13 & 5 & 31 & 12\end{array}$

$\begin{array}{lllllllll}.7 & 1.4 & 2.0 & -.0 & +.0 & -.3 & 2.3 & 2.3 & 2.1\end{array}$

$\begin{array}{lllllllll}34 & 229 & 138 & 34 & 229 & 138 & 33 & 178 & 120\end{array}$

Matriculation examina-

tion or matriculation

examination and

vocational school

Employed

Children

Families

$\begin{array}{lllllllll}.5 & 1.1 & 2.1 & -.2 & -.2 & -.3 & 2.4 & 2.6 & 2.2\end{array}$

Not employed

Children

Families

$\begin{array}{rrrrrrrrr}.6 & 1.2 & 2.8 & -.1 & -.0 & +.6 & 2.7 & 2.6 & 2.8 \\ 35 & 43 & 8 & 35 & 43 & 8 & 33 & 42 & 8\end{array}$

Total

Children

Families

$\begin{array}{lllllllll}.5 & 1.2 & 2.2 & -.2 & -.1 & -.1 & 2.5 & 2.6 & 2.3\end{array}$

Matriculation examination and vocationaltechnical college

Employed

Children

Families

$\begin{array}{rrrrrrrrr}.2 & 1.1 & 2.0 & -.5 & -.1 & -.3 & 2.2 & 2.3 & 2.1 \\ 16 & 167 & 53 & 16 & 167 & 53 & 15 & 141 & 46\end{array}$

Not employed

Children

$\begin{array}{lllllllll}.5 & 1.7 & 2.2 & -.3 & +.2 & +.3 & 2.3 & 2.8 & 2.3\end{array}$

Families

$\begin{array}{lllllllll}10 & 46 & 10 & 10 & 46 & 10 & 10 & 36 & 10\end{array}$

Total

Children

$\begin{array}{lllllllll}.3 & 1.3 & 2.0 & -.4 & -.1 & -.2 & 2.2 & 2.4 & 2.2\end{array}$

Families

$\begin{array}{lllllllll}26 & 213 & 63 & 26 & 213 & 63 & 25 & 177 & 56\end{array}$




\begin{tabular}{|c|c|c|c|}
\hline Education and work & $19-24 \quad 25-34 \quad 35-45$ & $\begin{array}{c}\text { „Excess» }(+) \text { or } \\
\text { »deficit» }(-) \text { of children } \\
\text { Wife's age in years } \\
19-24 \quad 25-34 \quad 35-45\end{array}$ & $\begin{array}{l}\text { Expected number of } \\
\text { children } \\
19-24 \quad 25-34 \quad 35-45\end{array}$ \\
\hline
\end{tabular}

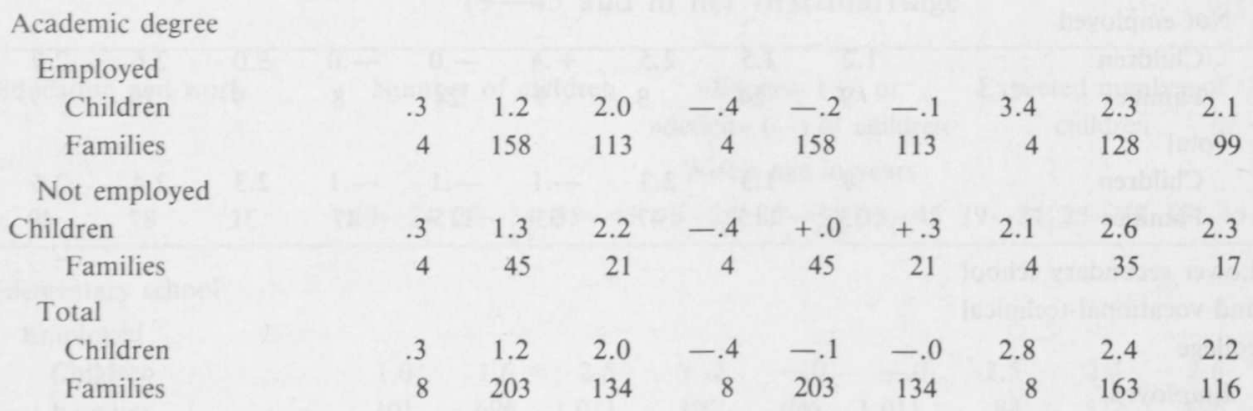


A p pendix t a ble 4. The relations of the wife's education and work with some variables concerning number of children according to a two-way analysis of variance (cf. Table 3)

\begin{tabular}{|c|c|c|c|c|c|}
\hline $\begin{array}{l}\text { Age class and the } \\
\text { variable to be } \\
\text { explained }\end{array}$ & $\begin{array}{l}\text { Variable and } \\
\text { interaction }\end{array}$ & F-value & $\begin{array}{l}\text { Degree of } \\
\text { freedom }\end{array}$ & $\begin{array}{l}\text { The probability } \\
\text { that the differ- } \\
\text { ence between } \\
\text { classes is caused } \\
\text { by chance, } \%\end{array}$ & $\begin{array}{c}\text { Degree of } \\
\text { explanation } \\
\text { of the } \\
\text { model, } \%\end{array}$ \\
\hline
\end{tabular}

Aged 19-24

\begin{tabular}{|c|c|c|c|c|c|}
\hline Number of live & Education & 13.9968 & $7, \quad 528$ & .1 & \\
\hline children & Work & 43.1183 & $1, \quad 528$ & .1 & 22.1 \\
\hline & Interaction & 0.8525 & $7, \quad 521$ & $>5.0$ & \\
\hline Number of children & Education & 8.0657 & $7, \quad 528$ & .1 & \\
\hline stabilized for length & Work & 48.4133 & $1, \quad 528$ & .1 & 18.0 \\
\hline of marriage & Interaction & 1.2978 & $7, \quad 521$ & $>5.0$ & \\
\hline Expected number of & Education & 0.9818 & 7,472 & $>5.0$ & \\
\hline children & Work & 4.5118 & 1,472 & 5.0 & 6.8 \\
\hline & Interaction & 2.8426 & 7, 465 & 1.0 & \\
\hline Aged 25-34 & & & & & \\
\hline Number of live & Education & 17.0531 & 7,2619 & .1 & \\
\hline children & Work & 92.5342 & 1,2619 & .1 & 7.9 \\
\hline & Interaction & 1.1913 & 7,2612 & $>5.0$ & \\
\hline Number of children & Education & 3.9834 & 7,2618 & .1 & \\
\hline stabilized for length & Work & 142.6778 & 1,2618 & .1 & 6.6 \\
\hline of marriage & Interaction & 1.6742 & 7,2611 & $>5.0$ & \\
\hline Expected number of & Education & 0.6400 & 7,2039 & $>5,0$ & \\
\hline children & Work & 50.1844 & 1,2039 & .1 & 3.0 \\
\hline & Interaction & 0.5929 & 7,2932 & $>5.0$ & \\
\hline Aged $35-45$ & & & & & \\
\hline Number of live & Education & 7.8629 & 7,2241 & .1 & \\
\hline children & Work & 7.0130 & 1,2241 & 1.0 & 2.9 \\
\hline & Interaction & 0.3132 & 7,2234 & $>5.0$ & \\
\hline Number of children & Education & 1.7609 & 7,2239 & $>5.0$ & \\
\hline stabilized for length & Work & 16.1166 & 1,2239 & .1 & 1.5 \\
\hline of marriage & Interaction & 0.3624 & 7,2232 & $>5.0$ & \\
\hline Expected number of & Education & 6.8133 & 7,1994 & .1 & \\
\hline children & Work & 3.9075 & 1, 1994 & 5.0 & 2.7 \\
\hline & Interaction & 0.2728 & 7,1987 & $>5.0$ & \\
\hline
\end{tabular}




\section{References}

Andorka, Rudolf: Determinants of Fertility in Advanced Societies. Methuen \& Co Ltd, London 1978.

Cochrane, Susan Hill: Fertility and Education. What Do We Really Know? World Bank Staff Occasional Papers. Number Twenty-Six. 1979.

Elinolosuhteet 1950-1975 - Living Conditions 1950-1975. Tilastollisia tiedonantoja N:o 58. Statistical Surveys No. 58. Tilastokeskus - Central Statistical Office of Finland. Helsinki 1977.

Haavio-Mannila, Elina: Suomalainen nainen ja mies. Asema ja muuttuvat roolit. WSOY, Porvoo Helsinki

Kerr, Clark, Dunlop, John T., Harbison, Frederick H., and Myers, Charles A.: Industrialism and Industrial Man. The Problems of Labor and Management in Economic Growth. Harvard University Press, Cambridge, Mass., 1960.

Kupinsky, Stanley: The Fertility of Working Women in the United States: Historical Trends and Theoretical Perspectives. In The Fertility of Working Women. A Synthesis of International Research. Ed. by Stanley Kupinsky. Praeger, New York 1977.

Laslett, Peter: Mean Household Size in England since the Sixteenth Century. In Household and Family in Past Time. Ed. by Peter Laslett and Richard Wall. Cambridge University Press, Cambridge, 1972.

Parsons, Talcott, and Bales, Robert F.: Family, Socialization and Interaction Process. The Free Press, Glencoe, Ill., 1955 .

Riihinen, Olavi, Pulkkinen, Aimo, and Ritamies, Marketta: Suomalaisen perheen lapsiluku. Väestöntutkimuslaitoksen julkaisusarja D. (Publications of the Population Research Institute, Series D), No. 7, 1980.

Ryder, N. B., and Westoff, C. F.: Reproduction in the Unites States. Princeton University Press, Princeton 1971.

Strömmer, Aarno: Väestöllinen muuntuminen Suomessa. Analyyttinen kuvaus syntyvyyden, kuolevuuden ja luonnollisen kasvun tähänastisesta kehityksestä ja alueellisesta vaihtelusta. Väestöpoliittisen tutkimuslaitoksen julkaisuja A:13 (Publications of the Population Research Institute, Series A13). Vammalan Kirjapaino Oy, Vammala 1969.

Suomen Virallinen Tilasto XL.2. Työvoimatiedustelu. Tilastokeskus. (Official Statistics of Finland XL.2. Labour Force Survey. Central Statistical Office.) Helsinki 1978.

Suominen, Leena: Lapsiperhe Suomessa. Väestöliitto, Kolmikantasarja 7. Helsinki 1979.

Säntti, Riitta and Väliaho, Heli: Lapsiperheiden palkaton kotityö: ajankäyttö ja arvo (Unpaid Housework in Families with Children: Time Use and Value). Suomen Virallinen Tilasto. Sosiaalisia erikoistutkimuksia XXXII:84 (Official Statistics of Finland. Special Social Studies XXXII:84). Sosiaali- ja terveysministeriö. Tutkimusosasto (Ministry of Social Affairs and Health. Research Department), Helsinki 1982. 